\title{
Pedagogical Innovation: Key Driver for the Educational Process of Future Industrial Engineers - The Case of Industrial University of Santander (UIS), Colombia
}

\author{
Orlando E. Contreras and Erika T. Ruíz
}

\begin{abstract}
The program of Bachelor of Science in Industrial Engineering at the Universidad Industrial de Santander (Colombia) has been developing projects of pedagogical innovation led by professors and students as a product of its Strategic Focus in search of its consolidation to be the most important program of Engineering in Colombia. This particular plan is described and analyzed in this article based on its content, form and level of impact. The purpose of making this study has determined the most useful and effective academic methodologies that help to define strategic approaches oriented to make adequate decisions for the improvement of the future performance of its former students. The findings show that the pedagogical strategies that favor the autonomous learning and facilitate the processes of a meaningful and cooperative learning are: 1) case methodology, 2) playful activities in the classrooms (ludic), and 3) laboratories; Strategies which are being applied transversely by using Information and Communication Technologies (ICT) in order to develop the skills required by the working environment of the future Industrial Engineers.
\end{abstract}

Index Terms-Learning, skills, teaching, pedagogical innovation.

\section{INTRODUCTION}

The School of Industrial Engineering and Business (known in Spanish as EEIE), guided by the Mission Statement of the UIS (Colombia), is an academic organization affiliated to the Faculty of Physical-Mechanical Engineering Fields, whose fundamental purposes of teaching, researching and making a social impact are centered in a comprehensive and professional training at undergraduate and graduate level in order to get professionals able to design, launch, lead, manage and improve generating systems of goods and services, contributing to the technological and business development of the company.

Currently, the school offers the bachelor's program of Industrial engineering and several graduate programs (four undergraduate and two master's degrees), it also has three research groups that support ongoing research activity. Fig. 1, shows the EEIE environment highlighting its main axis which is the industrial engineering program, as well as active research groups and their relationship to the branches of the

Manuscript received February 10, 2014; revised April 10, 2014. This work was developed by research group FINANCE \& MANAGEMENT for the School of Industrial Engineering and Business of Universidad Industrial de Santander (Bucaramanga, Colombia).

The authors are with Universidad Industrial de Santander, Calle 9 Carrera 27, Edificio de Ingeniería Industrial - Ciudad Universitaria, Bucaramanga, Colombia (e-mail: ocontrer@uis.edu.co, tatianaruizorjuela@gmail.com).
University.

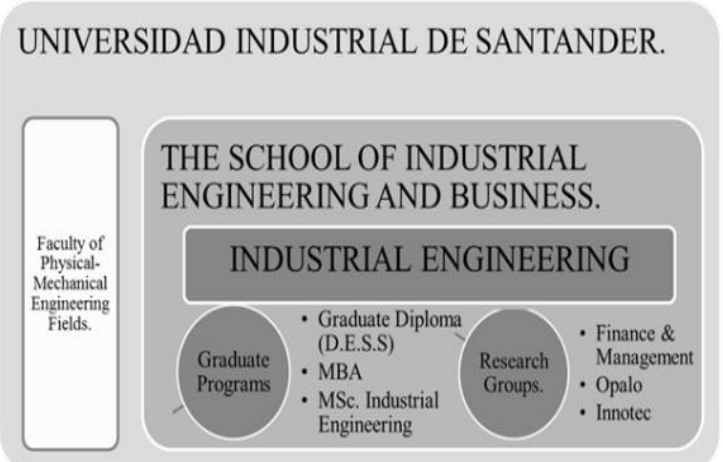

Fig. 1. School of Industrial Engineering and Business environment.

The Industrial Engineering program -created in 1961 and pioneer in Colombia- is an undergraduate academic program coordinated by the EEIE: it currently has 1615 students enrolled, 15 full-time teachers, 99 adjunct teachers and 3780 graduates.

As part of the process of high quality re-accreditation and design of the strategic plan of EEIE program has developed several innovation strategies. In accordance with the Institutional Project of the UIS, which establishes that "teachers must assume full commitment and awareness of ethics and social responsibility, the role of guiding the learning process and support the overall education of students." [1], the purpose of consolidating the axis of teaching through innovative education strategies in the classroom has been established in order to improve the teaching and learning of students in the program. As part of the design of the strategic plan of the School, the practices of the best universities in the world to develop innovative teaching processes were identified, and the specific actions that should be undertaken for the development of strategic projects activities were determined for the pedagogical innovation projects [2].

The activities described above were used for the formal definition of the Pedagogical Innovation Plan, which aims to: incorporate new teaching methods and evaluators as part of teaching methodologies and active learning to support the development of generic and cognitive skills of the Industrial Engineering Program.

\section{PRevious ExPERIENCES IN PEDAGOGICAL INNOVATION}

Activities and outcomes of professors and students who have advanced teaching innovation projects independently and spontaneously in order to modify and improve learning 
strategies were an important step for the projection of a superior purpose of the EEIE. The intervention of such events has been being developed in different courses of the industrial engineering program. Part of the purpose of this study is to understand the design, development and experience of pedagogical innovation processes taking place in the program, identifying the issues most commonly used in the development of these projects that allow us to identify the methodologies of teaching and learning most effective and highest impact for both teachers and students. Inventory of the projects is presented in Table I, and an overview of the design of innovation in terms of its content, form and level of impact is given [3].

From the experiences described in the table in the previous section, it is concluded that the pedagogical innovation developed seeks to employ teaching methods that foster independent learning and student motivation processes and facilitate meaningful learning, problem-based learning and cooperative learning. Activities in the process of educational innovation in the EEIE have been developed jointly by teachers and students and the idea of starting these projects arises on the initiative of the teacher or on graduation projects developed by students in the form of teaching practice. The reasons which are considered to initiate innovation is that the methodology currently used is theoretical, the contents are extensive and students show lack of care for the development of the subject. Based on this, it can be concluded that the main result of the innovation projects is associated with the development of innovative curriculum materials.

This implies a change in role of teacher as guide and facilitator in the process of student learning that contribute to program improvement and development of generic skills among which are included: developing strategies for teamwork, creative problem-solving and decision-making, improving interpersonal skills and communication skills.

\section{Plan of Pedagogical InNOVAtion For the EEIE}

Through these tools (a total of over 130 have been designed in the last 5 years) the School has sought to address the problem identified in the classroom, which was related to the low motivation of students because of the theoretical approach that was being given to subjects and the environment diagnosis where it was clear that professional graduates of universities had greater decision-making and implementation in real and complex scenarios [4].

The scope of what was originally formulated included three distinct approaches which, eventually, realized the desired strategic direction. Several discussions took place again and again within faculty meetings and in School Councils and Curricular and Graduation Projects Committees. Eventually agreement was reached on the road: 1) the use of case studies, 2) the investment and use of laboratories, and 3 ) the adoption of play as a support tool. The justification, appealing to those [5], is validated the moment an overlap is made between these internal capabilities (skills), opportunities in the academic and business environment (potential) and motivation to enter different territories that challenge teaching skills (passion), as shown in Fig. 2.

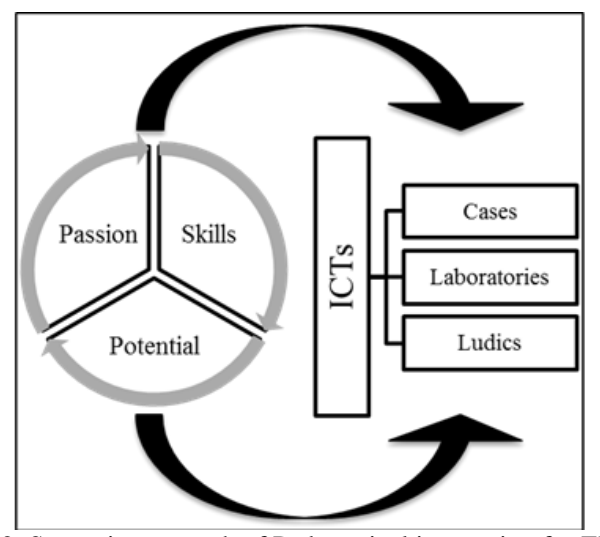

Fig. 2. Strategic approach of Pedagogical innovation for EEIE.

Additionally, it should be noted that, gradually, the use of ICTs began to become naturally in a cross element of the Plan of Pedagogical Innovation in the EEIE, because, in spite of having traditional on-campus classes, it was easily validated that the use of these technologies constituted practical pedagogical tools that facilitated the process of teaching and learning in the program courses, making use of techniques for transport and transmission of information and including the construction of virtual websites for the subjects and the design of physical spaces that serve as micro-worlds of the same.

\section{A. Case Methodology}

According to [6], the case study method emerges as initiative of Christopher C. Lang dell who introduced it in Harvard Law School as an alternative to the traditional teaching method that was nothing more than given lectures and evaluate by an oral board examination for students who had managed to memorize the legal textbooks. Then (in 1920) it was brought to the Business School of the University to position itself as an alternative method of teaching in other elite universities in the United States.

Preferring a more inductive and pragmatic approach than other teaching methods, the use of case methodology has become enormously popular in business schools around the world and it is common to see how it is present in academic life in general through freely data, specialized competitions and specific sections of specialized journals on topics relating to business administration.

There are even very reputable universities who come to use it as the only valid method of teaching programs for their post-graduate executive programs.

In recent years the rise of information technology has changed the way cases are prepared and discussed in the classroom to transform them into more attractive tools to students. Thus, it has become common that written common cases are accompanied by multimedia presentations and accessible via the Internet. The first case of HBS multimedia was recorded in 1996, it was the case of a Chinese textile company which included videos and an interactive worksheet. Today, multimedia cases are distributed online as part of the package of cases available for sale on the website of HBS. According to the statement by [7], the method of case study: 
TABLE I: INVENTORY OF THE PEDAGOGICAL INNOVATION PROJECTS

Design and development of a laboratory for logistics practices in the UIS[8].

Family Businesses in
Santander. A Case Study of
Lavco and Foto Serrano
Industries[9].
Design of experimental
practices for the subject
analysis process, using the
methodology of collaborative
learning [10].
Implementation of workshops
based on "Business Process
Management" software for the
Analysis of Process class[11].

Case Study of the Autotanques de Colombia Company as a teaching tool in the area of business management [12]

Case study as a teaching tool in the entrepreneurship course[13].

Creation of the Industrial Hygiene laboratory for the EEIE[14].

Designing of a teaching proposal for the business management II class which allows learning content through the implementation of different methodological strategies [15].

Design and implementation of an educational proposal based on information technology and communications for the Business Environment class [16].

Implementing pedagogical practical tools supported on techniques for processing and transmission of information on the Entrepreneurship course[17]. Entrepreneurship

Practical implementation with software tools specialized in the Project Management course supported in a virtual environment [18].
Designing the pedagogical mediation to be used by teachers in each of the proposed logistics laboratory practices. Facilitate student access to manual laboratory practice through web platform and evaluate the teaching strategy designed.

Identifying good practices with which family businesses in the region survive in the marketplace, through the building of their case studies.

Experimental planning practices based on the methodology of collaborative learning; running a pilot project to test the methodology and content of the practices of the subject and formulate a practical guide for teachers.

Designing, documenting, implementing and evaluating associated workshops in BPM software. Conducting a pilot test and evaluating the perceptions of students as to the methodology used, the design of the manual, the workshops and the applicability of software.

Building the case study with teaching notes to support the process of analysis and discussion of educational case. Generating supporting material through ICTs. Evaluating and analyzing the application of case study based on the views of students and teachers through surveys.

Documenting case studies of companies fostered by the Entrepreneurial Corporation Bucaramanga in written form, audio or video and use them as a teaching tool. Developing the respective evaluation process.

Designing the Practice Manual for Occupational Health, the User and Laboratory Equipment Manual, implementing in the Moodle platform content from every practice and evaluating the experiences proposed in the manual.

Perform benchmarking of different methodological strategies such as case study, reading, exhibitions, workshops and role play used in higher education administrative issues.

Defining, designing, implementing and evaluating pedagogical strategies to develop part or all of the cognitive and conceptual process of the subject, using different information and communication technologies that make plausible the didactic mediation between learners and content strategies proposed.

Generating and implementing practical pedagogical tools to facilitate the teaching-learning process, using techniques for transport and transmission of information, including the construction of a virtual site and the design of a physical space that serves as a laboratory for it.

Designing and developing guides, workshops, assessments, and other support material, focused on industrial engineering in the implementation of the selected tools, which will be the teaching material used in the development of teaching practice; uploading on the Moodle platform the proposed contents.
Practical classes. Laboratories.

Workshops.

Using ICTs.

Meaningful

learning.

Collaborative

learning.

Using ICTs.

\section{Meaningful}

learning.

Practical classes.

Assistance and

development of

workshops.

Participation in

interrogations.

Developing a

constructive and

expository

project.

Case studies.

Using ICTs.

Discussion of

ideas.

Debates.

\section{Case studies.}

Use of ICT's.

Practical

classroom

learning

Practical classes.

Laboratory.

Use of ICT's.

\section{Case studies.}

Workshops and

assignments.

Exhibitions.

Roleplays.

\section{Playful}

Activities.

Using ICTs.

Simulation,

animations,

workshops.

Case Studies.

Playful activities.

Using ICTs.

Ability to apply knowledge to practice in the surrounding environment, teamwork, communication skills.

Leadership, creativity, problem solving and decision making.

Greater dynamism in the class, understanding of concepts, decision making, self-learning, communicationskills development.

Application of learned concepts, problem solving, use of the Moodle platform.

Problem solving and decision-making responsibility, autonomy and creativity. Oral and written expression, teamwork.

\section{Problem-based}

learning.

Case studies.

Debates,

exhibitions,

forums,

discussion

seminars.

Using ICTs.
Virtual audiovisual aids and ability to work in teams and respect others' ideas and opinions, communication skills, applying knowledge to practice.

Problem solving, decision making, information search and selection, teamwork.
Innovative spirit, promoting entrepreneurship, development of a business model, business management software, team learning. 


\begin{tabular}{|c|c|c|c|}
\hline $\begin{array}{l}\text { Design and evaluation of a } \\
\text { methodology where } \\
\text { technological tools applied to } \\
\text { the subject analysis processes } \\
\text { are incorporated [19]. }\end{array}$ & $\begin{array}{l}\text { Designing appropriate educational audiovisual and } \\
\text { virtual tools so that the student's process is } \\
\text { continuous, clear and easy to understand. }\end{array}$ & $\begin{array}{l}\text { Meaningful } \\
\text { learning. } \\
\text { Collaborative } \\
\text { learning. } \\
\text { Self-directed } \\
\text { learning. }\end{array}$ & $\begin{array}{l}\text { Study materials with information technologies, } \\
\text { audiovisual tools, learning takes place } \\
\text { individually and in groups, real work } \\
\text { environments are recreated. }\end{array}$ \\
\hline $\begin{array}{l}\text { Implementation of workshops } \\
\text { based on Markov's Chains of } \\
\text { discrete time with stationary } \\
\text { probabilities for the Operations } \\
\text { Research II class [20]. }\end{array}$ & $\begin{array}{l}\text { Designing and implementing a tool comprised of } \\
\text { workshops, presentations, theoretical material, } \\
\text { quizzes and questions to facilitate the analysis of } \\
\text { Markov's Chains. }\end{array}$ & $\begin{array}{l}\text { Collaborative } \\
\text { learning. } \\
\text { Workshops. } \\
\text { Using ICTs. }\end{array}$ & $\begin{array}{l}\text { Individual and group responsibility, teamwork, } \\
\text { systemic and analytical thinking. }\end{array}$ \\
\hline $\begin{array}{l}\text { Design and simulation of a } \\
\text { production line for the real } \\
\text { environment manufacturing } \\
\text { lab[21]. }\end{array}$ & $\begin{array}{l}\text { Making proposals of distribution of installation } \\
\text { where the processes carried out in the laboratory } \\
\text { are incorporated and simulating alternatives for the } \\
\text { production line. }\end{array}$ & $\begin{array}{l}\text { Clases prácticas. } \\
\text { Laboratorios. } \\
\text { Talleres. } \\
\text { Uso de TIC's. }\end{array}$ & $\begin{array}{l}\text { Creative problem solving, development of } \\
\text { analytical and synthesis skills, application of } \\
\text { knowledge in real environments. }\end{array}$ \\
\hline $\begin{array}{l}\text { Implementation of workshops } \\
\text { based on Flexsim simulation } \\
\text { software for the Modern } \\
\text { Optimization Techniques } \\
\text { course[22]. }\end{array}$ & $\begin{array}{l}\text { Defining and proposing a methodology for } \\
\text { teaching and use of Flexsim and developing a } \\
\text { manual for learning and development of the } \\
\text { workshops designed. }\end{array}$ & $\begin{array}{l}\text { Experimental } \\
\text { practices. } \\
\text { Cooperative } \\
\text { learning. } \\
\text { Using ICTs. }\end{array}$ & $\begin{array}{l}\text { Management of specialized software for } \\
\text { problem-solving in teams. }\end{array}$ \\
\hline $\begin{array}{l}\text { Design and implementation of } \\
\text { innovation and creativity } \\
\text { games as a strategy for } \\
\text { teaching and learning in the } \\
\text { Entrepreneurship course[23]. }\end{array}$ & $\begin{array}{l}\text { Documenting a manual for teachers and one for the } \\
\text { student detailing the procedure for each game of } \\
\text { innovation and creativity developed and designing } \\
\text { a website based on the WIX online platform. }\end{array}$ & $\begin{array}{l}\text { Playful activities. } \\
\text { Experiential } \\
\text { learning. }\end{array}$ & $\begin{array}{l}\text { Learning inside and outside the classroom, } \\
\text { assimilation and application of concepts, } \\
\text { developing personal and professional skills. }\end{array}$ \\
\hline
\end{tabular}

"It is a profound educational innovation that presents the greatest challenges faced by leading companies, non-profit and nongovernmental organizations and placing the student in the role of decision making (...) In this method there is no single solution to the problem. Thus, through a dynamic process of exchanging perspectives, to argue and defend points of view, and build knowledge from the ideas of others, students gain the ability to analyze situations, exercise judgment and make difficult decisions; characteristics of experienced leadership."

Reference [24], defines case study as an organized educational dialogue on a real situation, in which experience is used as a method of knowledge transfer. On the other hand [25], associates it with the simulation of historical reality through the use of language. It starts with the exhibition of a particular case so that the student is able to understand, to know and analyze the whole context and the variables involved in the case. A good case should allow the existence of different solutions. According to the statement made by [26], case studies are qualitative methods that are used especially in the area of management and entrepreneurship, in which a fact of business reality and its stakeholders is described by defining company problem and the alternative solutions that arise. In it, the facts and people are considered as well as the views, experiences, knowledge and perceptions of the participants.

In conclusion, the case study is a method of teaching and research of great importance for the development of human and social sciences that involves a process of inquiry characterized by systematic and in-depth study of cases of a phenomenon, understanding these as social or educational entities and only following a common ethnographic methodology for the study of also common scenarios.

Utility of Case Methodology as Pedagogical Strategy: Reference [27], states that there are some fundamental reasons that support the effectiveness of the case method. One is that students develop their mental abilities better by evaluating real situations while applying theoretical concepts.
In addition, group work and interaction with other students are an effective preparation in the human aspects of management. Also adds that students voluntarily spend more time working independently when the case study is used since they feel it is more interesting than working exclusively with cases and theoretical lessons.

Reference [28], lists three principles identified in this didactic teaching model:

1) Learning from descriptions of practice: Learning is achieved by analyzing descriptions and examples of complex circumstances present, which were developed for this purpose.

2) Learning by problem-solving: Learning arises from the examples of open decision alternatives that are built with the elements of the case (free of responsibility for the effects of decisions)

3) Learning without explicit objectives: Learning is motivated by the characteristics of the case, but each student can explore aspects of personal interest.

Through an organized dialogue on a real situation, the method uses the experience to knowledge transfer. Meanwhile [29], argues that the discussion of the case is a mixture of rhetoric, dialogue, induction, intuition and reasoning: recreation, in short, the methodology of practical science, "the rationality of administrative tasks is a practical rationality using technical tools and prudently considers its validity and feasibility, bearing in mind the cultural and historical circumstances."

Case Methodology in the EEIE. Despite being a major player in executive education programs (postgraduate, diploma and master) taught for over 20 years in the School, it has only recently (since 2009) aroused the curiosity to incorporate the case method within the pedagogical strategies of some subjects of the curriculum of Industrial Engineering, and that is why the teachers in charge of the courses (formally called Business Management) of the administrative systematically searched opportunities to use it. The approach to other universities in Colombia and abroad and especially their business schools made it possible to better understand 
the system and incorporate it rigorously in the courses.

Courses, seminars, subscription databases, building teaching notes for their own and other cases, and ongoing assessment of the impact perceived by students have been constant since then in order not to lose momentum in the use of this tool courses in Management, Innovation, Human Resources, Sustainability and Entrepreneurship. Also, from this time, innumerable graduation works have been developed to a different extent to build national and local cases with the status of its application and follow-up in class as well as the use of ICTs. They have provided significant contributions to the courses regarding methodologies and improvement in proposals developed, diagnostics and benchmarking among others. One of the earliest works, specifically oriented to the Entrepreneurship course is best explained as follows:

Case Study as a Pedagogical Tool in the Entrepreneurship Course at the Industrial Engineering program, UIS. Practice in Teaching. With the goal of "documenting case studies of companies incubated by the Entrepreneurial Corporation of Bucaramanga and use them as a teaching tool in the creation of companies in the EEIE at UIS" the authors identified the need to use this technique in the class, taking into account the existence of a consensus in the literature on the relationship between education and entrepreneurial performance [30]. To achieve this, a number of activities including the selection of business ideas to document were implemented, choosing the appropriate methodology, taking into account each project, the development of relevant interviews with entrepreneurs and finally the application of the tool with its evaluation and feedback from faculty and stakeholders.

Inter alia, the following objectives, defined as products at the end of the project were intended:

1) Six case studies according to the topics developed in the course, documented in written form, audio and video.

2) Questionnaire for each case study in order to create space for debate and discussion.

Particularly, this work aimed to motivate students in reading and study cases that were not so extensive or confusing that would ultimately reduce their interest thereof and the learning process became limited in areas of entrepreneurship. Although the problem to be solved with the implementation of the game to the entrepreneurship lecture is directly related to the development of the creative potential of the student, it is worth saying that, as previously stated; within its many benefits we have intrinsic motivation, which moves people to perform some activity for the simple pleasure of it.

Within their analysis methodology, the authors conducted, inter alia, a benchmarking of the course, which meant a valuable contribution to the development of this work since one of the specific objectives to be achieved was to review good practices in subjects mainly related to entrepreneurship and to integrate techniques of creativity and innovation.

\section{B. Playful Activities in the Classroom (Ludic)}

Playful activities is today an alternative solution to a problem of teaching and learning how to develop content beyond the cognitive to achieve a transformation in the skills of the individual, to recreate microcosms where life experiences generate a cultural change.

Through their use, the construction of knowledge is encouraged and it is intended to overcome the difficulty of reductionism in traditional classes:

1) To remove barriers to communication between teacher and students: physical space, status, the teacher as the center of the educational process.

2) The phenomenon of the teacher as sole owner of the educational process.

3) Lectures, where students react to the information.

4) Passive participation of the student, where he is limited to the reception, storage and recall of knowledge.

5) Absence of critical judgment and creativity.

6) Loss of faculties of wonder and curiosity.

7) Stimulation of only linguistic and logical-mathematical intelligences.

Reference [31], highlights the benefits of playing as a teaching strategy: "The didactic or educational game is a participatory teaching technique designed to develop in students, methods of leadership and right conduct, thus stimulating discipline with an appropriate level of decision and self-determination, ie, not only fosters the acquisition of knowledge and skills development, but also contributes to the motivation for the subjects". Moreover [32], mentions some of the benefits that the use of play as a teaching strategy might include, for example that the play activity provides:

1) Immediate feedback. The game provides the student with information on their performance with the intention of allowing them to reinforce their strengths and overcome their weaknesses.

2) Information on demand. For the same game mechanics, information is a feature that should be available immediately which must be saved and learned, facilitating the learning process.

3) Productive learning. Having to learn in order to win or to access higher levels, requires from the user to carry out a process of productive and dynamic learning in which skills and abilities that can be used in reality are developed.

4) Intrinsic motivation. The atmosphere generated by the game involves some aspects of competition where the player tries to influence the outcome of the game and at the same time is attracted to this. Such behavior is described as intrinsic motivation, which has been recognized as one of the mechanisms of exploration and curiosity which aims at providing a context of commitment and self-reinforcement in which motivates and educates students.

5) It motives cycles of experience. Intrinsic motivation that gained from simply winning and having fun, drives the student to play again and again to become an expert who poses different strategies as well as a connoisseur of the game mechanics.

6) Self-regulated learning. The game encourages critical and active learning through enabling environments in which students enjoy the process of pursuing activities, achievement of objectives through decision making, knowledge building, trying different alternatives which can succeed or fail without concern for adverse consequences in real life. 
7) Teamwork. In the process of achieving the goals and win, teamwork becomes one of the main benefits of the game.

8) Transfer of Learning. Assimilation of information, concepts and knowledge are provided.

9) Assessment of learning. By looking at the different approaches or applications that the concepts being assimilated through the game may have, the student further assess the knowledge obtained.

10) Involvement of teachers. The game offers a social learning environment which aims to assist teachers and schools with a set of powerful tools to enhance student motivation and learning-related outcomes.

11) Technology infrastructure. Today there are not only video-games with the sole purpose of entertaining. Games based on electronic platforms are gaining strength in education institutions and commercial enterprises. Therefore, the technological infrastructure must meet the relevant requirements for the development of those.

The bet of the EEIE: Efforts to carry out the incorporation of playful tools into the curriculum of the Industrial Engineering program of the UIS have focused on 2 ways depending on teachers' orientations and motivations when approaching their courses. Thus the adoption of Design Thinking on the one hand as a tool to stimulate creativity and lateral thinking, and on the other hand the Classroom Simulation Class that focus on the discovery of the usual biases involved in industrial engineering decisions, are the favorite ways in which this purpose has become tangible.

The "Design Thinking", a different mindset: Thinking and acting as designers (not necessarily of products but models) has become an interesting practice that has redefined the traditional standards of innovation in business, bringing up the cultures of those organizations which, for one reason or another, have changed the rules of the business game: Apple, Google, Amazon, Starbucks and IKEA, among others. According to [33], Design Thinking is about "believing that you can make a difference through a defined process in order to obtain high-impact solutions. It also provides the necessary faith to believe in your creative skills since it allows people to adopt an approach of transforming problems into potential opportunities through design".

Design Thinking has (see Fig. 3) four main features:

1) Focus on people because it starts from a deep empathy and an understanding of the needs and motivations of human beings (students, teachers, parents, support staff, managers and general worldwide).

2) It is collaborative. It is proven that several heads make up a creative group with the greater potential than a single-head one. One of the greatest benefits of Design Thinking is that it provides multiple views and perspectives of the same problem to people in order to achieve creative and innovative solutions.

3) It is optimistic. Design Thinking believes that all people are agents of change, no matter how big the problem to be solved is or if you have the time or resources to do so. Regardless of the restrictions that exist around, design is a process that can be enjoyed widely.

4) It is experimental. Design Thinking is a process that accepts the occurrence of failures in order to learn from mistakes. This requires returning with new ideas, get the corresponding information and feedback in order to iterate later. It is for this reason that it is said that Design Thinking is always a "work in progress".

In summary, Design Thinking is the confidence that humans have in being able to create new and original things. This trust is the same that has allowed several developmental processes of some innovative products to be achieved as at the time it was the Apple mouse.

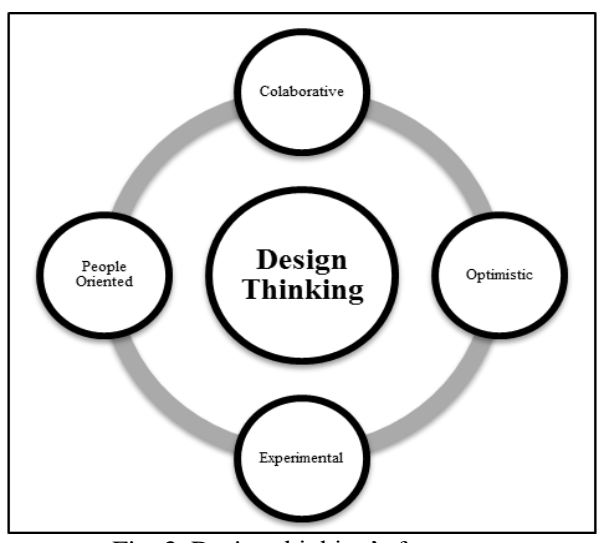

Fig. 3. Design thinking's features.

Without any doubt, it is necessary to spread this optimism spread in the current educational system.

It's use is limited to the subjects of Entrepreneurship and Innovation Management where lateral thinking (or "thinking outside the box") and creativity are tested to face situations that teachers include in the program content. The continued use of CANVAS Model welcomes us to think like visionaries, game changers, and challengers striving to defy outmoded business models and design tomorrow's enterprises [34].

Simulation Class in the Classroom: When we talk to simulate, we are referring to mimicking reality in a different, more manageable context and allow taking more controlled risks than in real life. And of course within a framework of traditional education, the fact of trying to get a teacher to have the ability to simulate reality in a classroom without adequate resources is complex in nature and therefore it is a natural resistance to change, especially in a program such as industrial engineering, where the decisions to be taken would represent quite "expensive" implications, as it were.

The bet is then to present more real teaching formats, where randomness, uncertainty and the unknown have their space. In that sense, the proposal of the Group of Playful Simulation Activities of the School of Industrial Engineering and Business. (GALEA due to its acronym in Spanish) is a learning laboratory, which, with playful methodology, proposes processes with unknown results and therefore, with space for a real constructivist social dynamics. Playful activities give another course of unanticipated results, without trying to say that the only educational alternative is playful, GALEA establishes its proposal from its results and research work; playful activities can be applied to many other pedagogies, and teaching methodologies. Currently, 4 teachers and 13 students are channeling efforts so that, in the framework of a rigorous protocol documentation, new physical (supported with tangible elements) or digital (software simulation) simulations can be adopted within the 
courses that so require.

The famous "beer game" for the subject of Logistics Management, popular due to its constant reference in the Fifth Discipline by Peter Senge (1993), is just one example of what to do in order to impart knowledge from the construction. Also the use of the Harvard Business Review platform for Educators gives us resources for topics such as leadership (Everest V2), Marketing (Managing Segments and Costumers V2) and Project Management (Scope, Resources, Schedule V2), among others.

\section{Laboratories}

Reference [35], concluded that the lab is a way of organizing the teaching-learning process. Some authors [36], [37], consider that the laboratory work requires the development of alternative curriculum materials, on the other hand [38], says that teaching through research and practice provides teachers the opportunity to have their students develop skills to enrich the scientific and technical knowledge; in turn [39], states that discovery teaching has been the supporting basis to state that students find motivation in direct practice.

Reference [40], states that scientific laboratories involve an environment where students have access to concepts, to solve problems, and experiments in the same space (being theory and practice inseparable); these interactive experiences and practices give quicker results and students use these results to design and capitalize discovery. In academia, laboratory exercises are used as teaching tools to reinforce the knowledge acquired in the teaching-learning process; in the education sector, the laboratory experience provides the opportunity for students to develop communication skills, leadership and cooperation [41]. Meanwhile [39], notes that lab practices contribute to the acquisition of skills transferable to other areas of study and valid as a means to address everyday problems that occur outside the laboratory; based on the above, it is concluded that the practices of engineering lab allow students to develop skills they will use in their professional practice.

Laboratory Methodology at the EEIE: The curriculum of the Industrial Engineering program considers the development of practical and laboratory experiences in several of its subjects the basic cycle of science; meanwhile, for the professional cycle, the School, through its building improvement and modernization project, has designed laboratories for the development of core subjects such as: Process Analysis and Measurement of Work, Quality Engineering, Safety and Design of Manufacturing Systems, Flexible Manufacturing and Logistics Laboratories corresponding to the management process line. With the results obtained through experience and evaluation of the creation of laboratory practice in the Industrial Engineering program developed in the pedagogical innovation projects, it is concluded and validated that this teaching-learning strategy of promotes capacity in students focused on problem solving of real situations through the application of the theory.

\section{CONCLUSION}

The use of innovative strategies in the curriculum of the
Industrial Engineering program allows a better teaching system of basic and complex concepts related to the profession. Through them, the learning process becomes more efficient due to the low-cost tools needed, the easiness of handling them, their effectiveness in understanding non-technical concepts related to specific education; their contribution to make classes more dynamic they use to be; and their orientation to obtain a collaborative process.

With the results obtained through the application of laboratory practices for the industrial engineering program, we could find that this pedagogical strategy promotes the development of skills in students focused on problem solving of real situations through the application of the theory.

The use of ludic allows knowledge construction through a healthy environment (even in a competitive one) where the important thing is to make sense of new learning, beyond a preset schedule or "blind" acceptance of knowledge.

This article makes clear that the application of Case Methodology as a teaching tool in educational programs is not limited to certain areas of knowledge and professions such as law or business, but it is valid to address a number of real problems since through the Socratic method (analytical questions) strengthening the judgment and discernment of the student as well as improving their public speaking and ability to stimulate the debate; which are important elements to be worked by future industrial engineers.

With the methodology of the case, the faculty of the EEIE, found an additional interesting as a possible publication of research opportunity per case (plus their respective teaching note) also encourages the writing of their socialization experiences, along with the results obtained through events and journals in order to obtain greater productivity and academic visibility.

For the above reasons, authors recommend the use of innovative practices in higher education such as ludic activities, case studies and laboratories, given the positive results early in its implementation at the EEIE at UIS. The use of such techniques motivates students and facilitates the maintenance of interest especially in large classes with high content exhibition by the professor.

The focus of learning should not be missed out and therefore the seriousness in the implementation of these practices is a sine qua non condition for the professor and for the students from the beginning. Susceptibility to take things lightly is real as the academic environment evolves into a more relaxed one and can become particularly confusing to some students who tend to misinterpret the signals.

Although the effectiveness of this innovation plan is measured by the perceived satisfaction of the user (student), it is much more important and accurate to measure it by defining their usefulness in real life. Unfortunately, this is a measurement that is made in an ex post scenario and requires appropriate communication mechanisms to address the graduates in order to capture their impressions in a firsthand way.

\section{REFERENCES}

[1] Universidad Industrial de Santander, Proyecto Institucional UIS, p. 20, 2000 .

[2] L. Serrano, "Diseño de un plan estratégico para la Escuela de Estudios Industriales y Empresariales," Universidad Industrial de Santander. Bucaramanga, Colombia, p. 92, 2013. 
[3] M. Zabalza, "Innovación en la Enseñanza Universitaria," Contextos Educativos, vol. 6-7, pp. 113-136, 2003-2004.

[4] A. C. Pedrazaand and E. Bravo, "Cambios en las herramientas pedagógicas,videos de casos sobre emprendimientos innovadores locales," Revista de la Escuela de Administración de Negocios, no. 71, pp. 84-99, Jul.-Dec. 2012.

[5] J. C. Collins and J. I. Porras, "Building your company's vision," Harvard Business Review, pp. 65-77, Sep.-Oct. 1996, reprinted 2006.

[6] J. C. Ickis and F. Leguizamon, "Lineamientos para escritura de casos didácticos," IESE Publishing, INCAE 0158, December 2011.

[7] Harvard Business School. The HBS Case Method. [Online] Available: http://www.hbs.edu/mba/academic-experience/Pages/the-hbs-case-me thod.aspx.

[8] C. Soler and M. Guechá, "Diseño y desarrollo de un laboratorio para realizar prácticas de logística en la Universidad Industrial de Santander," undergraduate dissertation, Universidad Industrial de Santander, Bucaramanga, 2003.

[9] P. Martínez and J. Torres, "Empresas familiares en Santander. Un estudio de caso de Industrias Lavco y Foto Serrano," undergraduate dissertation, Universidad Industrial de Santander, Bucaramanga, 2012.

[10] M. Lesmez and J. Sandoval, "Diseño de las prácticas experimentales para la asignatura análisis de procesos, mediante la metodología de aprendizaje colaborativo," undergraduate dissertation, Universidad Industrial de Santander, Bucaramanga, 2012.

[11] M. Fiallo and C. Pizano, "Implementación de talleres basados en software 'Business Process Management' para la asignatura análisis de procesos," undergraduate dissertation, Universidad Industrial de Santander, Bucaramanga, 2010.

[12] D. Ortiz, "Caso de estudio de la empresa Autotanques de Colombia S.A.S como herramienta pedagógica," undergraduate dissertation, Universidad Industrial de Santander, Bucaramanga, 2013.

[13] J. Díaz and G. Filomena, "Estudio de casos como herramienta pedagógica en la asignatura creación de empresas," undergraduate dissertation, Universidad Industrial de Santander, Bucaramanga, 2011

[14] S. Carreño and S. Mendoza, "Creación del laboratorio de higiene industrial," undergraduate dissertation, Universidad Industrial de Santander, Bucaramanga, 2013

[15] D. Gómez and P. Medina, "Diseño de una propuesta didáctica para la asignatura dirección empresarial II que permita el aprendizaje de los contenidos a través de la implementación de diferentes estrategias metodológicas," undergraduate dissertation, Universidad Industrial de Santander, Bucaramanga, 2012

[16] V. Robles and R. Carreño, "Diseño e implementación de una propuesta didáctica basada en tecnologías de la información y comunicaciónpara la asignatura entorno empresarial," undergraduate dissertation, Universidad Industrial de Santander, Bucaramanga, 2011.

[17] N. Martínez and M. Velásquez, "Implementación de herramientas pedagógicas practicas apoyadas en técnicas para el tratamiento y transmisión de la información en la asignatura creación de empresa," undergraduate dissertation, Universidad Industrial de Santander, Bucaramanga, 2012.

[18] N. García and L. Rendón, "Implementación de práctica con herramientas software especializadas en la asignatura gestión de proyectos soportada en un ambiente virtual," undergraduate dissertation, Universidad Industrial de Santander, Bucaramanga, 2010

[19] N. Peña and J. Trujillo, "Diseño y evaluación de una metodología donde se incorporen herramientas tecnológicas aplicadas a la asignatura análisis de proceso," undergraduate dissertation, Universidad Industrial de Santander, Bucaramanga, 2010.

[20] J. Araque, "Implementación de talleres basados en Cadenas de Markov de tiempo discreto con probabilidades estacionarias para la asignatura de investigación de operaciones II," undergraduate dissertation, Universidad Industrial de Santander, Bucaramanga, 2010.

[21] J. Peña, "Diseño y simulación de una línea de producción para el laboratorio de ambiente real de manufactura," undergraduate dissertation, Universidad Industrial de Santander, Bucaramanga, 2012

[22] W. Pinto, "Implementación de talleres basados en el software de simulación Flexsim," undergraduate dissertation, Universidad Industrial de Santander, Bucaramanga, 2011.

[23] C. Useda, "Diseño e implementación de juegos de innovación y creatividad como estrategia de enseñanza y aprendizaje en la asignatura creación de empresas," undergraduate dissertation, Universidad Industrial de Santander, Bucaramanga, 2013.

[24] M. Muñoz and V. H. Santoyo. (December 2013). Guía metodológica para la redacción de estudios de casos. Universidad Autónoma De Chapingo. [Online]. Available: http://bv.ciestaam.edu.mx/attachments/article/72/Munoz\%20Manrrubi
o--Guia\%20metodologica\%20para\%20redaccion\%20de\%20estudios $\% 20 \mathrm{de} \% 20$ caso.pdf.

[25] OEA. (December 2, 2013). El método del caso. Universidad Politécnica de Madrid. [Online]. Available: http://innovacioneducativa.upm.es/documentos/academicos/Guias.pdf

[26] A. M. Rusque and C. Castillo, Métodos de caso: Su construcción y animación para la interacción docente, Santiago: Editorial Universidad Santiago de Chile, p. 293, 2006.

[27] M. Reynolds, M. Sclater, and S. Tickner, A critique of participative discourses adopted in networked, learning, presented at Networked Learning Conference, 2004.

[28] E. Schiefelbein. (December 2, 2013). Modelos didácticos para América Latina. Guía metodológica para la redacción de estudios de caso. Agencia interamericana para la cooperación y el desarrollo. [Online] Available:

http://www.carlosmoreno.info/upn/pdf/Flechsig,\%20Schiefelbein_20 03_Veinte\%20modelos\%20did\%C3\%A1cticos\%20para\%20am\%C3 $\%$ A9rica\%20latina.pdf

[29] R. F. Crespo, "The epistemological status of managerial knowledge and the case method, Second ISBEE World Congress, The ethical challenges of globalization," in Proc. Latin America, pp. 210-8. 2000.

[30] A. H. Charney and G. Libecap, "The impact of entrepreneurship education: An evaluation of the Berger entrepreneurship program at the University of Arizona, 1985-1999," Kauffman Research Series, Kansas City, MO: Ewing Marion. Kauffman Foundation, 2000.

[31] D. Oblinger, "The next generation of educational engagement," Journal of interactive Media in Education, vol. 8, pp. 1-18, 2004.

[32] T. S. Chung. (2012). Table-top role playing game and creativity. Thinking Skills and Creativity. [Online]. 8. pp. 56-71. Available: http://dx.doi.org/10.1016/j.tsc.2012.06.002

[33] T. Brown (2010). Design thinking>Approach. IDEO. [Online] Available: www.ideo.com/thinking/approach

[34] A. Osterwalder and Y. Pigneur, Business Model Generation, 1st. Ed., Amsterdam, The Netherlands, Modderman Drukwerk, pp. 4-14, 2009.

[35] J. Praia and L. Marqués, "El trabajo de laboratorio en la enseñanza de la geología: Reflexión crítica y fundamentos epistemológico-didácticos," Enseñanza de las Ciencias de la Tierra, vol. 45, no. 2, pp. 95-106, 1997.

[36] D. Gil and J. Payá, "Los trabajos prácticos de Física y Química y la metodología científica," Revista de Enseñanza de la Física, vol. 2, pp. 73-79, 1988.

[37] P. Tamir and M. García, "Características de los ejercicios de prácticas de laboratorio incluidos en los libros de textos de ciencias utilizados en Cataluña," Enseñanza de las Ciencias, vol. 10, pp. 3-12, 1992.

[38] National Research Council, National Science Education Standards, Washington: National Academy Press, ch. 4, p 68, 1996.

[39] D.Hodson, "The ontario institute for studies in education, investigación y experiencias didácticas: Hacia un enfoque más crítico del trabajo de Laboratorio," Enseñanza de las Ciencias, vol. 12,no. 3, pp. 299-313, 1994.

[40] W. McKeachie and M. Svinicki, Teaching Tips Strategies, Research, and Theory for College and University Teachers, 2nd ed., Houghton Mifflin Company, USA, ch. 20, 2006.

[41] L.Guadalupe, "La importancia de los laboratorios," Construcción y tecnología, pp. 20-22, 2006.

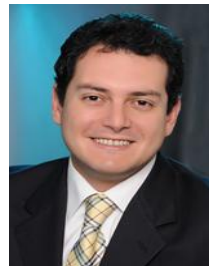

Orlando E. Contreras was born in Ocaña, Colombia in 1976. He got his bachelor degree in industrial engineer and specialized in executive management from Universidad Industrial de Santander, Bucaramanga, Colombia, 2001. He obtained his master of business administration from Tulane University, New Orleans, LA, USA, 2007

$\mathrm{He}$ is an assistant professor of the School of Industrial Engineering and Business of Universidad Industrial de Santander.

He has published several papers in the area of finance, human resources and sustainability, as a member of Research Group: Finance \& Managent of Universidad Industrial de Santander.

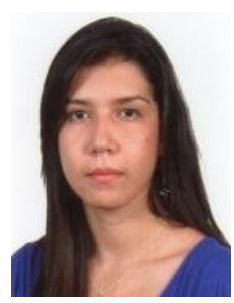

Erika T. Ruíz was born in Duitama, Colombia in 1989. She earned her bachelor degree in industrial engineering from Universidad Industrial de Santander, Colombia in 2013

She is an administrative in the School of Industrial Engineering and Business, where she develops activities for Research and Administrative, the following themes stand out: curriculum evaluation curriculum reform and competency-based curriculum. 